\title{
Efficacy of Lactic Acid Bacteria Isolated from Some Fruits and Vegetables
}

\author{
Feriala A A. Abu Saif
}

Botany Dept., College of Women for Arts, Science and Education, Ain Shams University, Cairo, Egypt .

\begin{abstract}
7 HE CURRENT study was conducted to assess the extent of probiotics Lactic acid bacteria(LAB) in some fresh fruits as (peach, pashmala, ,apricot, grape, banana, yellow and red apple, Kiwi, guajava and orange) and some vegetables as (cucumber, tomato and strawberry). Thirty eight (38) isolates were Gram positive and catalase negative, 20 isolates belong to genus Lactobacillus and 18 belong to Lactococcus sp. According to biochemical reactions 13 isolates out of 38 were identified as 5 belong to L. plantarum, 2 isolates to L. brevis, 3 to Pediococcus sp. and 3 to Leuconostoc sp. Antagonistic activity of these isolates against Staphylococcus aureus ATCC6538, Escherichia coli ATCC8739, Pseudomonas aeruginosa ATCC 9027 and Salmonella typhimurium ATCC22 bacteria were assessed. It noticed that some isolates have a negative effect against all the tested isolates, other isolates affected on some tested strains and some isolates affected on all tested strains. In all the cases that have affected the inhibition area not exceeding $5 \mathrm{~mm}$. Sensitivity to commercial antibiotics were studied and it noticed that the isolates showed sensitivity to antibiotics varies among the least sensitive isolate, Leuconostoc sp. 26, where it was sensitive to only one antibiotic and the most senior sensitivity was L.plantarum 5 and 27 strains which showed sensitivity to 11 out of 14 antibiotics that were tested. Probiotics characteristics showed that all isolates were sensitive to low stomach $\mathrm{pH} 3$ and for $0.3 \%$ bile salt, only six isolates were resistant to bile salts $0.3 \%$ concentration after $4 \mathrm{~h}$; four of Lactobacilli strains (L.plantarum 1, 5 and 38 and L. brevis11) and two of Lactococci (Pediococcus sp. 18 and Leuconostoc sp. 21).
\end{abstract}

Keywords: Probiotics, Lactic acid bacteria, Bile salt, Antagonistic, Sensitivity

Vegetables and fruits are fundamental sources of water-soluble vitamins (vitamin $\mathrm{C}$ and group B vitamins), provitamin A, phytosterols, dietary fibres, minerals and phytochemicals (Gebbers, 2007) for the human diet. Scientific evidences encouraged the consumption of vegetables and fruits to prevent chronicpathologies such as hypertension (Dauchet et al., 2007), coronary heart diseases and the risk of stroke (He et al., 2007). Unfortunately, the daily intake of vegetables and fruits is estimated to be lower than the doses (400 g, excluding potatoes and other starchytubers) recommended by the World Health Organization (WHO), and Food and Agriculture Organization (FAO)). 
The word probiotic comes from the Greek word " $\pi \rho 0-\beta i$ c $\varsigma$ " that means "for life"; thus, probiotics are live microorganisms (mainly bacteria but also yeasts) that confer a beneficial effect on the host if administered in proper amounts (Perricone et al., 2014).

Microorganisms play an essential role in the food fermentations, lactic acid bacteria (LAB) has the main role, it is involved for thousands of years in food fermentations and are one of the most ancient preservation techniques, first signs of LAB utilizations date back to $6000 \mathrm{BC}$, describing the fermentation of milk and fermentation of meat 1500BC and vegetable products 300BC ( Fox, 1993) Lactic acid bacteria (LAB) have been extensively studied for their commercial potential (Lilian \& Aida, 2006) food preservation and health benefits (Pierre, 2002). They are industrially important microorganisms used worldwide mainly in the dairy industry for manufacturing fermented milk products and cheese. Industrial importance of LAB is based on their ability to ferment sugars readily into different metabolites and provide an effective method for preserving fermented food products. These bacteria are Gram positive, non-spore forming and naturally present in media rich in organic products such as food products (Pierre, 2002). LAB is, however, a genetically diverse group of bacteria encompassing widely recognized genera, which include: Carnobacterium, Enterococcus, Lactobacillus, Lactococcus, Leuconostoc, Oenococcus, Pediococcus, Streptococcus, Tetragenococcus, Vagococcus and Weissella (Chen, 2002). Some authors include the genus Bifidobacterium because of its probiotic role, although it belongs to a different phylogenetic group (Vandamme et al., 1996). Moreover, although many representatives of LAB are perfectly safe and used for generations in food, some species are pathogens such as pathogenic Streptococci (Adams, 1999).

Identification of LAB based on carbohydrate fermentation patterns is unreliable and not accurate enough to distinguish closely related strains due to their similar nutritional requirements (Perricone et al., 2014) Sequencing analysis of the 16s RNA genes has been used to determine the diversity and dynamics of LAB in food (Jung-Min et al ., 2010; Nongpanga et al., 2008 and Chen et al., 2005). Lactic acid bacteria are a small part of the autochthonous microbiota of vegetables and fruits. The diversity of the microbiota markedly depends on the intrinsic and extrinsic parameters of the plant matrix. Notwithstanding the reliable value of the spontaneous fermentation to stabilize and preserve raw vegetables and fruits, a number of factors are in favour of using selected starters. Two main options may be pursued for the controlled lactic acid fermentation of vegetables and fruits: the use of commercial/allochthonous and the use of autochthonous starters. Several evidences were described in favour of the use of selected autochthonous starters, which are tailored for the specific plant matrix. Pro-technological, sensory and nutritional criteria for selecting starters were reported as well as several functional properties, which were recently ascribed to autochthonous lactic acid bacteria (Raffaella et al., 2013). Currently available reports indicate that probiotics, prebiotics, synbiotics, feed enzymes, organic

Egypt. J. Microbiol. 51 (2016) 
acids, essential oils and immunostimulants repre-sent some of the key substitutes worthy of consideration (Huyghebaert et al., 2011).

Fruit juices represent a promising carrier for probiotic bacteria; however, there are some drawbacks and limits that could preclude their production at the industrial level, namely the survival of probiotics throughout storage, and the possible impact of bacteria on the sensory traits and overall acceptance (Perricone et al., 2015).

Bamidele et al. (2011) isolated four lactic acid bacteria as follows: Pediococcus pentosaceus 2 from cucumber, Lactobacillus cellobiosus from cabbage, Lactobacillus salivarius and Lactobacillus plantarum 1 from lettuce. Nevertheless, lactic acid bacteria have a number of well-established and potential benefits. They can improve lactose digestion, play a role in preventing and treating diarrhea and act on the immune system, helping the body to resist and fight infection. More work needs to be done to authenticate the role lactic acid bacteria which might play in antitumor effects, hyper cholesterol effects, preventing urogenital infections, alleviating constipation and treating food allergy. This research work was designed to isolate Lactic acid bacteria from some vegetables (cucumber, tomato and strawberry) and some fruits as (banana, kiwi, guajava, red and yellow apple and orange), investigate its antimicrobial activity, probiotic characteristics and its sensitivity to commercial antibiotics.

\section{Materials and Methods}

\section{Sample collection}

Lactic acid bacteria (LAB) were isolated from 50 samples of fresh fruits and vegetables, obtained from different Cairo markets. Samples consisted of two groups: group I, 10 types of (peach, pashmala, , apricot, grape, banana,yellow and red apple, kiwi, guajava and orange) types of fresh fruit (33 samples); group II, 3 types of raw whole (cucumber, tomato and strawberry ) vegetables (17samples) (Table 1). The samples packaged into sterile plastic containers, transported to the laboratory and processed immediately to prevent deterioration (Trias et al., 2008a) .

Isolation and purification of lactic acid bacteria

Ten gram each, of fresh fruits or vegetables sample were homogenized in $10 \mathrm{ml}$ of sterile distilled water by vortexing and transferred to $90 \mathrm{ml}$ of sterile de Man Rogosa Sharpe (MRS) broth (Oxoid, UK), in a sterile conical flask and mixed well. The decimal dilutions of the homogenates were prepared in a $0.85 \%$ sterile saline solution and plated on MRS agar media (De Man et al., 1960) containing bromocresol green $(25 \mathrm{mg} / \mathrm{l})$, based on the method of Dal Bello \& Hertel (2006) . The plates were incubated at $37^{\circ} \mathrm{C}$ for $48 \mathrm{~h}$ in an aerobic conditions. Isolated colonies were then picked from each plate and transferred to the MRS agar. The growth was processed for pure culturing, and the morphological characteristics of well-separated colonies in the MRS agar medium were recorded. The pure cultures were maintained in the MRS broth at $4^{\circ} \mathrm{C}$. All the cultures were sub cultured at 15 - day intervals. 
TABLE 1. Sources and number of isolated Lactic acid bacteria.

\begin{tabular}{|c|c|c|c|c|c|}
\hline $\begin{array}{l}\text { Isolate } \\
\text { number }\end{array}$ & sources & CAT & GM & Mor & LAC \\
\hline 1 & Cucumber & - & + & $\mathrm{R}$ & + \\
\hline 2 & Cucumber & - & + & $\mathrm{C}$ & + \\
\hline 3 & banana & - & + & $\mathrm{C}$ & + \\
\hline 4 & Cucumber & - & + & $\mathrm{C}$ & + \\
\hline 5 & Kiwi & - & + & $\mathrm{R}$ & + \\
\hline 6 & banana & - & + & $\mathrm{R}, \mathrm{st}, \mathrm{dib}$ & + \\
\hline 7 & banana & - & + & $\mathrm{C}, \mathrm{st}$ & + \\
\hline 8 & banana & - & + & C,st & + \\
\hline 9 & guava & - & + & R,sho & + \\
\hline 10 & guava & - & + & $\mathrm{R}$,sho & + \\
\hline 11 & guava & - & + & $\mathrm{R}$ & + \\
\hline 12 & Red apple & - & + & $\mathrm{R}, \mathrm{dib}$ & + \\
\hline 13 & Red apple & - & + & $\mathrm{R}, \mathrm{dib}$ & + \\
\hline 14 & Tomatoes & - & + & $\mathrm{R}, \mathrm{dib}$ & + \\
\hline 15 & Tomatoes & - & + & $\mathrm{R}, \mathrm{dib}$ & + \\
\hline 16 & Tomatoes & - & + & $\mathrm{R}, \mathrm{dib}$ & + \\
\hline 17 & banana & - & + & $\mathrm{R}, \mathrm{dib}$ & + \\
\hline 18 & Orange & - & + & $\mathrm{C}$ & + \\
\hline 19 & banana & - & + & $\mathrm{R}$ & + \\
\hline 20 & banana & - & + & $\mathrm{R}$ & + \\
\hline 21 & Cucumber & - & + & $\mathrm{C}, \mathrm{St}$ & + \\
\hline 22 & Orange & - & + & $\mathrm{R}$, di & + \\
\hline 23 & Orange & - & + & $\mathrm{R}, \mathrm{di}$ & + \\
\hline 24 & Orange & - & + & $\mathrm{R}, \mathrm{di}$ & + \\
\hline 25 & Orange & - & + & $\mathrm{R}, \mathrm{di}$ & + \\
\hline 26 & Y. apple & - & + & $\mathrm{C}, \mathrm{St}$ & + \\
\hline 27 & Y. apple & - & + & $\mathrm{R}, \mathrm{di}$ & + \\
\hline 28 & Y. apple & - & + & C,di, St & + \\
\hline 29 & Y. apple & - & + & C,di, St & + \\
\hline 30 & Y. apple & - & + & $\mathrm{C}, \mathrm{di}, \mathrm{St}$ & + \\
\hline 31 & Y. apple & - & + & $\mathrm{C}, \mathrm{di}, \mathrm{St}$ & + \\
\hline 32 & Y. apple & - & + & $\mathrm{C}, \mathrm{St}$ & + \\
\hline 33 & Y .apple & - & + & $\mathrm{C}, \mathrm{St}$ & + \\
\hline 34 & Red apple & - & + & $\mathrm{C}, \mathrm{di}$ & + \\
\hline 35 & Red apple & - & + & $\mathrm{C}$,di & + \\
\hline 36 & Yellow apple & - & + & $\mathrm{C}$,di & + \\
\hline 37 & Yellow apple & - & + & $\mathrm{C}, \mathrm{di}$ & + \\
\hline 38 & Tomatoes & - & + & $\mathrm{R}$ & + \\
\hline
\end{tabular}

CAT $=$ Catalase reaction $/ \mathrm{GM}=$ Gram stain $/ \mathrm{MOR}=$ Morphology $/ \mathrm{LAC}=$ Lactose utilization

-= Negative reaction $/+=$ Positive reaction $/ \mathrm{R}=$ Bacillary form $/ \mathrm{C}=$ Spherical form

$\mathrm{St}=$ Streptococci or Streptobacilli $/ \mathrm{di}=$ in pairs $/ \mathrm{Sh}=$ Short

Egypt. J. Microbiol. 51 (2016) 
Morphological ,Biochemical and physiological characterization of lactic acid bacteria isolates

Lactic acid bacteria characteristics presented in Bergey's Manual of Determenative Bacteriology (Holt et al., 2000). The pure cultures were identified according to their cultural, morphological (Macroscopic appearance of all the colonies were examined for cultural and morphological characteristics, size, shape, color and texture of the colonies were recorded), biochemical and physiological characteristics up to the biochemical tests used were Gram reaction; production of catalase (was carried out by adding few drops of freshly prepared 3\% hydrogen peroxide (Analar) to each plate containing $18 \mathrm{~h}$ old culture of each isolate) and cytochrome oxidase activity; growth at $10^{\circ} \mathrm{C}, 37$ and $45^{\circ} \mathrm{C}$ and lactic acid production (Aslam \& Qazi, 2010). The biochemical and acid production from sugar fermentation $(1 \% \mathrm{w} / \mathrm{v})$ lactose, glucose, aribinose , fructose, sucrose and raffinose

\section{Standard strains}

The standard strains used in this study were Staphylococcus aureus ATCC6538, Escherichia coli ATCC8739, Pseudomonas aeruginosa ATCC 9027 and Salmonella typhimurium ATCC22 bacteria . The strains were obtained from TCS bioscience LTD,Botolph Claydon. Buckingham, MK $1821 \mathrm{R}$. The cultures were grown on universal medium (UM) slants at $30^{\circ} \mathrm{C}$ for $24 \mathrm{~h}$ and maintained at $4^{\circ} \mathrm{C}$ in a refrigerator.

In vitro anti-microbial activity using spot-on-lawn method

After $18 \mathrm{~h}$ incubation, active cultures were spotted on the surface of MRS agar plates; The plates were incubated to grow cultures for 24 hours at $37^{\circ} \mathrm{C}$ under aerobic conditions. Overnight indicator pathogens were inoculated into soft agar containing 0.7\% agar. Staphylococcus aureus ATCC6538, Escherichia coli ATCC8739, Pseudomonas aeruginosa ATCC 9027 and Salmonella typhimurium ATCC22 as test reference pathogens.The inoculated agar was overlaid on MRS plates and incubated at $37^{\circ} \mathrm{C}$ which is appropriate for human pathogens. At the end of the incubation, inhibition zone diameters surrounding the spotted isolates were measured. Isolates which gave an inhibition zone bigger than $10 \mathrm{~mm}$ was determined to have antimicrobial activity.

\section{Antibiotic susceptibility assay}

The antibiotics used for susceptibility assay were Cestinaxane sulbctam $(30 \mu \mathrm{g})$ Pipercillin $(100 \mu \mathrm{g})$, ceftrxan $(30 \mu \mathrm{g})$, cefuroxine $(30 \mu \mathrm{g})$,Amoxicillin/ clavubaric acid $(30 \mu \mathrm{g})$, cefoxitin $(30 \mu \mathrm{g})$, teiocoplanine $(30 \mu \mathrm{g})$, azithromycin $(15 \mu \mathrm{g})$, gentamycin $(10 \mu \mathrm{g})$, Ofloxacine $(5 \mu \mathrm{g})$, sulphamethoxazole/ trimethoprim $(25 \mu \mathrm{g})$, Levofloxacin $(5 \mu \mathrm{g})$, chloramphenicol $(30 \mu \mathrm{g})$ and erythromycin $(15 \mu \mathrm{g})$, (Oxoid Ltd, England). The antibiotics were selected due to their common use in local Gram positive and Gram negative bacteria. A total of $1 \mathrm{ml}$ LAB culture grown in MRS broth was collected by centrifugation at $1000 \times \mathrm{g}$ for $5 \mathrm{~min}$. The cell pellet was collected and washed twice using $1 \mathrm{ml}$ of $0.85 \%$ (w/v) $\mathrm{NaCl}$, followed by suspending the cell pellet with $0.5 \mathrm{ml}$ of $0.85 \%$ (w/v) $\mathrm{NaCl}$. The cell suspension was adjusted to $0.5 \mathrm{Mc}$ Farland by using $2 \mathrm{ml}$ of $\mathrm{NaCl} 0.85 \%$ (w/v) prior to spread plate on MRS 
agar. The antibiotic disc was then placed on MRS agar plate. The diameter of inhibitory zones was measured after $48 \mathrm{~h}$ of incubation at $30^{\circ} \mathrm{C}$ under aerobic condition. The assay was conducted in triplicates (Bauer et al., 1966).

\section{Screening of isolated lactic acid bacterial genera for probiotic properties}

Resistance to low $\mathrm{pH}$

Resistance to $\mathrm{pH} 3$ is often used in vitro assays to determine the resistance to stomach pH. Food usually stays in the stomach for $3 \mathrm{hr}$ and this time limit was taken into account ( Prasad et al. 1998). Active cultures were incubated for 16 - 18 hours in MRS broth. The cells were harvested by centrifugation, washed once in phosphatesaline buffer (PBS at pH 7.2), resuspended in PBS (pH 3) and incubated at $37^{\circ} \mathrm{C}$. Viable microorganisms were enumerated at the $0,1,2$ and $3 \mathrm{~h}$ with the pour plate technique. Dilutions were done and the resulting plates were incubated at $37^{\circ} \mathrm{C}$ under aerobic conditions for $48 \mathrm{hr}$. The growth was also monitored at OD 620 using a T70 UV: VIS spectrometer PG Instruments Ltd.

\section{Bile salts tolerance}

The mean intestinal bile concentration is believed to be $0.3 \%(\mathrm{w} / \mathrm{v})$. The staying time of food in small intestine is suggested to be $4 \mathrm{~h}$ (Prasad et al., 1998). The experiment was applied at this concentration of bile for $4 \mathrm{~h}$. MRS medium containing $0.3 \%$ bile (Oxoid) was inoculated with active cultures which had been incubated for 16 - $18 \mathrm{~h}$ ). During the $4 \mathrm{~h}$ incubation at $0.3 \%$ bile, viable colonies were enumerated for every hour with the pour plate technique and growth was also monitored at 620 Optical Density-OD 620 .

\section{Statistical analysis}

Standard deviation has been calculated for the studied samples. In addition, the obtained data were treated statistically using analysis of variance as described by Snedecor \& Cockran (1969).

\section{Results and Discussion}

Taxonomy of lactic acid bacteria (LAB) represents a ubiquitous and heterogeneous species with common feature of lactic acid production. Taxonomically, LAB species are found in two distinct phyla, namely Firmicutes and Actinobacteria. Within the Firmicutes phylum, LAB belongs to the Lactobacillales order and includes the following Genera: Lactobacillus, Lactococcus, Leuconostoc, Oenococcus, Pediococcus, Streptococcus, Enterococcus, Tetragenococcus, Aerococcus, Carnobacterium, Weissella (Kocková et al., 2011), Alloiococcus, Symbiobacterium and Vagococcus which are all low guanine-cytosine (GC) content organisms (31-49\%). Within the Actinobacteria phylum, LAB belongs to the Atopobium and Bifidobacterium Genera, with a GC content of 36-46\% and $58-61 \%$,respectively. More generally, however, the term "LAB" does not reflect a phyletic class, but rather the metabolic capabilities of this heterogeneous bacterial group, the most important of which is the capacity to ferment sugars primarily into lactic acid. LAB are also characterized by being Gram positive, catalase negative, nonsporulating organisms that

Egypt. J. Microbiol. 51 (2016) 
are devoid of cytochromes and of non aerobic habit but are aero tolerant, fastidious, non-motile, acid tolerant and strictly fermentative; lactic acid is the major end product of sugar fermentation (Kocková et al., 2011; Pfeiler \& Klaenhammer, 2007 and Axelsson 1998 ).

However, not all LAB are beneficial in foods as some produce lipase and protease which degrade fats and proteins leading to food spoilage (Kalui et al., 2010). In the present study, three genus, Streptococcus, Leuconostoc and Lactobacillus according to Gram stain, microscopic examination and other biochemical reactions were isolated. Probiotics have been defined a number of times. Presently the most common definition is that from the FAO/WHO which states that probiotics are "live microorganisms that, administered in adequate amounts, confer a health benefit on the host." One of the most significant groups of probiotic organisms are the lactic acid bacteria, commonly used in fermented dairy products. There is an increase in interest in these species as research is beginning to reveal the many possible health benefits associated with lactic acid bacteria. The difficulty in identifying and classifying strains has complicated research, since benefits may only be relevant to particular strains. In the present study we isolated 38 isolates of Lactic acid bacteria (LAB), LAB colonies were found to be non motile, catalase negative and Gram positive, 20 isolates belong to Lactobacillus Genera which are tiny rods which occur in singly, pairs and chains, . and other 18 are belong to Lactococcus genera which were cocci and they occur singly, diblo and chains. According to some biochemical, physical and morphological characteristics of thirteen isolates showed that of 7 Lactobacillus isolates 5 represent Lactobacillus plantarum and 2 isolates represent L. brevis. Six cocci isolates were 3 of Pediococcus sp. and 3 of Leuconostoc sp. (Table 2). Emerenini et al. (2013) isolated Lactobacillus plantarum, Pediococcus pentosaceus and Lactobacillus pentosus from fresh vegetable; while Leuconostoc paramensenteroides , Lactobacillus plantarum, Lactobacillus paraplantarum and Lactobacillus pentosus were identified from fresh fruits. Di Cagno et al. (2009) demonstrated that strains of L. plantarum, Weissella cibaria/confusa, L. brevis, Pediococcus pentosaceous, Lactobacillus sp. and E. faecium/faecalis were identified from raw tomatoes by Biology System. Fifty-four lactic acid bacteria were isolated from spoiled fruits and vegetables as Lactobacillus acidophilus, L. paracasei, L. delbrueckii, L. casei, $L$. helveticus, L. brevis, L. salivarius, L. fermentum, $L$. rhamnosus, L. animalis, and L. plantarum Manzoor et al. 2016). Trias et al. (2008b) isolated $496 \mathrm{LAB}$ isolates from fresh fruits and vegetables.

\section{Antagonistic activity of lactic acid bacteria isolates}

The results showed the diversity of lactic acid bacteria isolates ability against some strains of bacterial pathogens, Staphylococcus aureus ATCC6538, Escherichia coli ATCC8739, Pseudomonas aeruginosa ATCC 9027 and Salmonella typhimurium ATCC22 as test reference pathogens between what is, some isolates have a negative effect against all the tested strains, other isolates affected on some tested strains and some isolates affected on all tested strains. In all the cases that have affected the inhibition area not exceeding $5 \mathrm{~mm}$. On the other hand, Tajudeen et al. (2011) recorded strong antimicrobial activity of LAB isolated from cucumber,Lettuce and Cabbage from Nigeria this may be due to the vegetable is spoiled or irrigated with polluted water as in the case of Manzoor et al. (2016) who isolated antagonistic LAB from spoiled 
fruits and vegetables which have the growth inhibition zone (GIZ) over 10 $\mathrm{mm}$ against all the uropathogenic test organisms ( Candida albicans, Klebsiella pneumoniae, Pseudomonas aeruginosa, Escherichia coli and Enterococcus fecalis.) where L. fermentum and L. plantarum, E. coli and E. faecalis, with a GIZ up to $28 \mathrm{~mm}$. On the other hand, Lactobacillus brevis strains that isolated from dairy products and fermented tomatoes juice produced antimicrobial compounds (Rushdy \& Gomaa, 2013 and Fatima \& Fernado, 2016). Trias et al. (2008b) isolated 496 LAB strains from fruits and vegetables, only 5 strains produced antimicrobial compounds.

TABLE 2. Biochemical tests for the identification of isolated lactic acid bacteria.

\begin{tabular}{|c|c|c|c|c|c|c|c|c|c|c|c|c|c|}
\hline \multirow{2}{*}{$\begin{array}{l}\text { ID. } \\
\text { parameter }\end{array}$} & \multicolumn{13}{|c|}{ LAB isolates } \\
\hline & Lb1 & Lb5 & Lb10 & Lb11 & Lb13 & Lb27 & Lb38 & Lc3 & Lc18 & Lc21 & Lc26 & Lc30 & Lc36 \\
\hline $\begin{array}{l}\text { Growth } \\
\text { at } 10^{\circ} \mathrm{C}\end{array}$ & - & - & - & - & - & - & - & - & - & - & - & - & - \\
\hline $\begin{array}{l}\text { Growth at } \\
37^{\circ} \mathrm{C}\end{array}$ & + & + & + & + & + & + & + & + & + & + & + & + & + \\
\hline Motality & - & - & - & - & - & - & - & - & - & - & - & - & - \\
\hline Gram & + & + & + & + & + & + & + & + & + & + & + & + & + \\
\hline Oxidase & - & - & - & - & - & - & - & - & - & - & - & - & - \\
\hline Catalase & - & - & - & - & - & - & - & - & - & - & - & - & - \\
\hline Mor & $\mathrm{R}$ & $\mathrm{R}$ & $\mathrm{R}$ & $\mathrm{R}$ & $\mathrm{R}$. & R. & $\mathrm{R}$ & C.di & C.di & C St & C.St & C.St & C.di \\
\hline Lact & + & + & + & + & + & + & + & + & + & + & + & + & + \\
\hline Glu & + & + & + & + & + & + & + & + & + & + & + & + & + \\
\hline . $\mathrm{Ar}$ & + & + & + & + & + & + & + & + & + & + & + & + & + \\
\hline Fructose & + & + & - & - & + & + & + & + & + & + & + & + & + \\
\hline Sucrose & + & + & - & - & + & + & + & - & - & ND & ND & ND & - \\
\hline Sus.bact & L.plant. & L.plant. & L.brevis & L.brevis & L.plant. & L.plant. & L.plant. & P.sp. & P.sp. & $\begin{array}{c}\text { Leuco- } \\
\text { nostoc } \\
\text { spp. }\end{array}$ & $\begin{array}{c}\text { Leuco- } \\
\text { nostoc } \\
\text { spp. }\end{array}$ & $\begin{array}{c}\text { Leuco- } \\
\text { nostoc } \\
\text { spp. }\end{array}$ & P.sp. \\
\hline
\end{tabular}

$\mathrm{ID}=$ identification /GM : Gram stain/ Mor: morphology; LAC: Lactose utilization /CAT: Catalase utilization $/ \mathrm{GLU}=$ Glucose utilization $/ \mathrm{Ar}=$ arabinose utilization $/$ Fructose $=$ utilization

Sucrose utilization $/ \mathrm{ND}=$ not detected / Growth at 10 and $37{ }^{\circ} \mathrm{C}=$ growth temperature at 10 and 37

L. plant $=$ Lactobacillus plantarum $/$ L.brevis $=$ Lactobacillus brevis Mor $=$ Morphology

$P$. sp. $=$ Pediococcus species Sus. Bact $=$ suspected Lactic acid bacteria

Sensitivity test of the lactic acid bacteria isolates to different antibiotics

Results illustrated in Table 3 showe that the highest potent antibiotic is chloramphinicol where it recorded antagonistic effect against all the tested Lactic acid bacterial (12) strains and the inhibition zone ranged from 10 to $30 \mathrm{~mm}$, followed by erythromycin antibiotic where it showed antagonistic effect against 9 of the 12 bacterial isolates with inhibition zone ranged from Egypt. J. Microbiol. 51 (2016) 
10 to $25 \mathrm{~mm}$, then followed by azithromycin showed antimicrobial activity against 7 isolates, levofloxacin 1 and teiocoplanine illustrated antagonistic activity against 6 bacterial isolates, cestinaxane sulbctam,cefuroxine and gentamycine gave antagonistic activity against 5 isolates, pipercillin, amoxicillin clavubaric and cefoxitin show antagonistic activity against only 3 bacterial isolates, but ofloxacine inhibited 2 isolates and finally sulphamethox trimthopirine only inhibited one bacterial isolates and ceftrxan have any effect on any isolates. It noticed that Leuconostoc sp. 26 the most resistant where it was affected by one antibaiotic and L. plantarum. 5 and 27 were the highest sensitive where they affected by 11 antibaiotics out of 14 antibiotics. This in the same line of Roushdy \& Goma (2013) and Kacem \& Karam (2006) where they reported that LAB strains were susceptible to most of the antibiotics tested and resistance was observed in case of cefixime, nalidixic acid, vancomycin and oxacillin. This is not in accordance with other reports indicating that LAB are normally resistant to the principal antibiotics, such as penicillin G, ampicillin, vancomycin, cloramphenicol or ciprofloxacin (Halami et al., 2000 and Coppola et al., 2005)

\section{Probiotic characteristics}

In order to be able to have beneficial effects on the human gut, a candidate potential probiotic strain is expected to have a number of properties. Probiotic strains do not need to fulfill all of the selection criteria but the most important ones are required (Quwehand et al. 1999 and (Çakir, 2003). One of the major important criteria is that probiotic destined for human usage should be of human origin (Çakir, 2003). Resistance to $\mathrm{pH} 3.0$ is often used in vitro assays to determine the resistance to stomach $\mathrm{pH}$. Food usually stays in the stomach for $3 \mathrm{~h}$ and this time limit was taken into account (Prasad et al., 1998). The results of the tolerance to acidic pH ( survival percentage of $\mathrm{LAB}$ isolates at $\mathrm{pH}$ value are shown in Fig. 1). The tested isolates (13 of Lactobacillus and Lactococcus) survived incubation periods of $1-3 \mathrm{~h}$ at $\mathrm{pH} 3.0$ with a decrease in survival percentage when the exposure time for isolates progressed. Similar observations for L.brevis were recorded by Roushdy \& Goma (2013). Partially this results were reported by Oluwajoba et al. (2013) they found that variation within each isolated LAB specie cultured at $\mathrm{pH} 3.0$ with respect to time. According to Roushdy \& Goma (2013) and Charteris et al. (1997) enteric Lactobacilli are usually able to tolerate $\mathrm{pH} 3.0$ for a few hours, $\mathrm{pH} 2.0$ for several minutes, while viable count will be affected at slightly high acidic $\mathrm{pH}$ and $\mathrm{pH} 1.0$ all the Lactobacillus species are destroyed.

Tolerance to bile salts represented a prerequisite for colonization and metabolic activity of bacteria in the small intestine of the host (Havenaar et al., 1992). Bile salts are surface- active chemicals produced in the liver from the catabolism of cholesterol. So, when evaluating the potential of using $\mathrm{LAB}$ as effective probiotics, it is generally considered necessary to evaluate their ability to resist the effects of bile acids ( Lee \& Salminen, 1995) . 


\begin{tabular}{|c|c|c|c|c|c|c|c|c|c|c|c|c|c|c|c|}
\hline & 象 & $\begin{array}{l}0 \\
\ddot{1}\end{array}$ & $\begin{array}{l}0 \\
\text { \# }\end{array}$ & $\begin{array}{l}0 \\
0 \\
0\end{array}$ & $\begin{array}{l}\text { ㅂ } \\
0\end{array}$ & $\begin{array}{l}0 \\
\ddot{1} \\
0\end{array}$ & $\begin{array}{l}\text { ㅇ } \\
0\end{array}$ & $\begin{array}{l}0 \\
0 \\
0\end{array}$ & $\begin{array}{l}0 \\
\text { 1 }\end{array}$ & $\begin{array}{l}0 \\
0 \\
0\end{array}$ & $\begin{array}{l}0 \\
\text { \#̈ }\end{array}$ & \begin{tabular}{|l|} 
\\
\\
0
\end{tabular} & 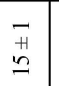 & 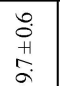 & 용 \\
\hline & 矛 & $\begin{array}{l}0 \\
\text { ㅍ }\end{array}$ & $\begin{array}{l}0 \\
\text { ㅂ }\end{array}$ & $\begin{array}{l}0 \\
\text { \# }\end{array}$ & $\begin{array}{l}0 \\
\dot{0} \\
0\end{array}$ & $\begin{array}{l}0 \\
\ddot{1} \\
0\end{array}$ & $\begin{array}{l}0 \\
\text { 1 }\end{array}$ & $\begin{array}{l}0 \\
+1 \\
0\end{array}$ & $\begin{array}{l}0 \\
\text { 1 }\end{array}$ & $\begin{array}{l}0 \\
\ddot{0}\end{array}$ & $\begin{array}{l}0 \\
\ddot{1} \\
0\end{array}$ & $\begin{array}{l}\text { 잉 } \\
\text { 1 }\end{array}$ & 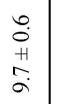 & $\begin{array}{l}\underset{7}{\#} \\
\stackrel{2}{2}\end{array}$ & 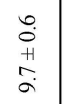 \\
\hline & 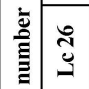 & $\begin{array}{l}0 \\
\ddot{1} \\
0\end{array}$ & $\begin{array}{l}0 \\
\text { ㅂ }\end{array}$ & $\begin{array}{l}0 \\
\text { 1 }\end{array}$ & $\begin{array}{l}0 \\
\text { H }\end{array}$ & $\begin{array}{l}0 \\
\ddot{1} \\
0\end{array}$ & $\begin{array}{l}0 \\
\text { 1 }\end{array}$ & $\begin{array}{l}0 \\
0 \\
0\end{array}$ & $\begin{array}{l}0 \\
\ddot{1} \\
0\end{array}$ & $\begin{array}{l}0 \\
\ddot{1} \\
0\end{array}$ & $\begin{array}{l}0 \\
\text { +1 } \\
0\end{array}$ & \begin{tabular}{|l|} 
\\
+ \\
0
\end{tabular} & $\begin{array}{l}0 \\
+1 \\
0\end{array}$ & $\begin{array}{l}\bar{y} \\
\stackrel{7}{n}\end{array}$ & $\begin{array}{l}0 \\
\ddot{1} \\
0\end{array}$ \\
\hline & 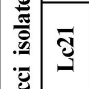 & $\begin{array}{l}0 \\
\ddot{1} \\
0\end{array}$ & 藏 & $\begin{array}{l}0 \\
\text { H }\end{array}$ & $\begin{array}{l}0 \\
\text { 풍․ }\end{array}$ & $\begin{array}{l}0 \\
\dot{1} \\
0\end{array}$ & $\begin{array}{l}0 \\
\ddot{1} \\
0\end{array}$ & 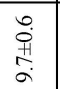 & 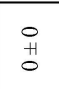 & $\begin{array}{l}0 \\
\ddot{0} \\
0\end{array}$ & $\begin{array}{l}0 \\
\text { O } \\
0\end{array}$ & \begin{tabular}{l|}
0 \\
+ \\
0
\end{tabular} & $\begin{array}{l}0 \\
\text { 1 } \\
0\end{array}$ & 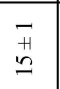 & 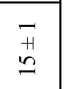 \\
\hline & $\frac{\infty}{3}$ & 劳 & $\begin{array}{l}0 \\
\text { ㅇ } \\
0\end{array}$ & $\begin{array}{l}0 \\
\text { +1 } \\
0\end{array}$ & 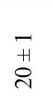 & 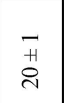 & $\begin{array}{l}0 \\
\ddot{1} \\
0\end{array}$ & \begin{tabular}{l|}
0 \\
+1 \\
0
\end{tabular} & $\begin{array}{l}0 \\
\text { H }\end{array}$ & $\begin{array}{l}0 \\
+ \\
0\end{array}$ & $\begin{array}{l}\tilde{H} \\
\stackrel{H}{n}\end{array}$ & $\begin{array}{l}0 \\
\text { +1 } \\
0\end{array}$ & $\begin{array}{l}0 \\
0 \\
+ \\
+ \\
6\end{array}$ & 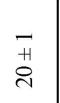 & $\begin{array}{l}\bar{F} \\
\ddot{n}\end{array}$ \\
\hline$\widehat{\mathrm{E}}$ & 3 & $\begin{array}{l}0 \\
\text { OH }\end{array}$ & $\begin{array}{l}0 \\
\text { ㅍ }\end{array}$ & $\begin{array}{l}0 \\
\text { 1 }\end{array}$ & $\begin{array}{l}0 \\
\text { ㅇ }\end{array}$ & $\begin{array}{l}0 \\
\text { +1 }\end{array}$ & 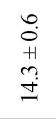 & $\begin{array}{l}0 \\
0 \\
+ \\
+1 \\
= \\
=\end{array}$ & $\begin{array}{l}0 \\
0 \\
\dot{0} \\
\stackrel{1}{0} \\
\stackrel{0}{0}\end{array}$ & $\begin{array}{l}0 \\
\ddot{0}\end{array}$ & $\begin{array}{l}\text { ㅇ } \\
\text { +1 }\end{array}$ & $\begin{array}{l}0 \\
\text { in } \\
0\end{array}$ & $\begin{array}{l}0 \\
\stackrel{0}{0} \\
+ \\
0 \\
\stackrel{1}{0}\end{array}$ & $\begin{array}{l}0 \\
\dot{0} \\
+ \\
0 \\
\dot{0} \\
\dot{J}\end{array}$ & $\begin{array}{l}0 \\
0 \\
0 \\
0 \\
0 \\
\stackrel{0}{0}\end{array}$ \\
\hline 总 & $\begin{array}{l}\infty \\
\substack{0 \\
=}\end{array}$ & \begin{tabular}{|l|} 
\\
0 \\
$\dot{0}$ \\
$\tilde{O}$ \\
$\stackrel{0}{0}$
\end{tabular} & 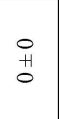 & $\begin{array}{l}0 \\
\text { ㅁ }\end{array}$ & $\begin{array}{l}\text { ㅇ } \\
\text { 망․ }\end{array}$ & $\begin{array}{l}0 \\
+1 \\
0\end{array}$ & 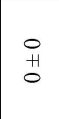 & $\begin{array}{l}\text { in } \\
0 \\
+ \\
i \\
i n\end{array}$ & $\begin{array}{l}\text { in } \\
o \\
+ \\
\text { H. } \\
\end{array}$ & $\begin{array}{l}\sqrt{n} \\
0 \\
0 \\
+ \\
0 \\
\end{array}$ & $\begin{array}{l}0 \\
\text { ㅂ }\end{array}$ & $\begin{array}{l}0 \\
+1 \\
0\end{array}$ & $\begin{array}{l}0 \\
\text { ㅁ } \\
0\end{array}$ & 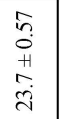 & $\begin{array}{l}n \\
\text { in } \\
0 \\
0 \\
0 \\
a \\
0\end{array}$ \\
\hline 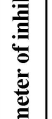 & $\begin{array}{l}\hat{3} \\
3 \\
3\end{array}$ & $\begin{array}{l}\hat{2} \\
0 \\
+1 \\
0 \\
\end{array}$ & 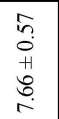 & $\begin{array}{l}0 \\
\text { \# }\end{array}$ & $\bar{H}$ & $\stackrel{-}{+}$ & $\stackrel{\text { \# }}{=}$ & $\begin{array}{l}0 \\
0 \\
+1 \\
⿱ 亠 䒑 \\
\therefore\end{array}$ & 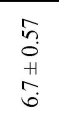 & $\begin{array}{l}0 \\
\text { \# }\end{array}$ & $\begin{array}{l}n \\
\tilde{n} \\
+ \\
\vdots \\
\vdots \\
\vdots\end{array}$ & $\begin{array}{l}0 \\
\text { +1 } \\
0\end{array}$ & $\begin{array}{l}\bar{H} \\
\vec{A}\end{array}$ & $\begin{array}{l}\begin{array}{l}0 \\
0 \\
0 \\
0 \\
0\end{array} \\
\end{array}$ & 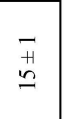 \\
\hline 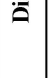 & 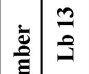 & そ & 文 & ₹ & 之 & 之 & 至 & ₹ & 乏 & 主 & $\mathrm{z}$ & 之 & $\hat{z}$ & 之 & 之 \\
\hline & 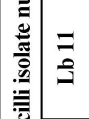 & $\begin{array}{l}n \\
\text { in } \\
0 \\
0 \\
e \\
n \\
n\end{array}$ & $\begin{array}{l}0 \\
\text { म } \\
0\end{array}$ & $\begin{array}{l}0 \\
\text { \# }\end{array}$ & $\begin{array}{l}\stackrel{0}{0} \\
+ \\
\stackrel{+}{a}\end{array}$ & $\begin{array}{l}\text { in } \\
\text { in }\end{array}$ & $\begin{array}{l}0 \\
\text { 1 }\end{array}$ & $\begin{array}{l}0 \\
+1 \\
0\end{array}$ & $\begin{array}{l}\bar{H} \\
\text { 莕 }\end{array}$ & $\vec{H}$ & $\begin{array}{l}0 \\
\text { ï }\end{array}$ & \begin{tabular}{l|}
0 \\
$\dot{1}$ \\
0
\end{tabular} & $\begin{array}{l}0 \\
\text { in }\end{array}$ & $\begin{array}{l}\vec{H} \\
\vec{D} \\
\text {. }\end{array}$ & $\begin{array}{l}0 \\
\stackrel{0}{0} \\
+1 \\
a \\
a\end{array}$ \\
\hline & 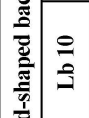 & $\begin{array}{l}0 \\
\text { 1 } \\
0\end{array}$ & $\begin{array}{l}0 \\
\text { + }\end{array}$ & $\begin{array}{l}0 \\
\text { 1 }\end{array}$ & $\begin{array}{l}0 \\
\text { +1 }\end{array}$ & $\begin{array}{l}\text { ㅇ } \\
\text { 10 }\end{array}$ & $\begin{array}{l}\text { ㅍ } \\
0\end{array}$ & $\begin{array}{l}0 \\
\text { ㅁ }\end{array}$ & $\begin{array}{l}\text { H } \\
\stackrel{0}{0} \\
\dot{ \pm}\end{array}$ & $\stackrel{\vec{H}}{=}$ & $\begin{array}{l}0 \\
\text { मे }\end{array}$ & $\left|\begin{array}{l}0 \\
0 \\
+ \\
\vdots \\
a \\
0\end{array}\right|$ & $\begin{array}{l}\text { in } \\
\text { in }\end{array}$ & 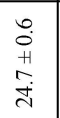 & $\begin{array}{l}0 \\
\text { 1 }\end{array}$ \\
\hline & 3 & $\begin{array}{l}0 \\
+1 \\
\infty\end{array}$ & $\begin{array}{l}5 \\
5 \\
0 \\
+ \\
6 \\
\end{array}$ & $\begin{array}{l}0 \\
\text { 1 }\end{array}$ & $\stackrel{\overrightarrow{1}}{\stackrel{1}{8}}$ & 咅 & $\begin{array}{l}\bar{\infty} \\
\infty\end{array}$ & 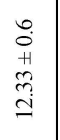 & $\begin{array}{l}\stackrel{0}{0} \\
\dot{0} \\
\stackrel{0}{0} \\
\stackrel{i}{i}\end{array}$ & 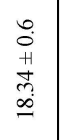 & 융 & 융 & $\begin{array}{l}0 \\
0 \\
+ \\
0 \\
0 \\
= \\
=\end{array}$ & $\begin{array}{l}0 \\
0 \\
+1 \\
0 \\
0 \\
0 \\
0\end{array}$ & $\stackrel{\bar{H}}{\underline{ \pm}}$ \\
\hline & $\overline{3}$ & $\begin{array}{l}0 \\
\text { H }\end{array}$ & $\begin{array}{l}0 \\
\text { \# }\end{array}$ & $\begin{array}{l}0 \\
\text { ㅁ }\end{array}$ & $\begin{array}{l}\infty \\
0 \\
0 \\
01 \\
0 \\
0\end{array}$ & $\begin{array}{l}\text { ㅁ } \\
\text { \#̈ }\end{array}$ & $\begin{array}{l}\text { ㅍ } \\
0\end{array}$ & $\begin{array}{l}\infty \\
0 \\
0 \\
+1 \\
0 \\
0 \\
0 \\
0\end{array}$ & 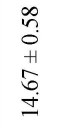 & $\begin{array}{l}\vec{H} \\
\stackrel{H}{2}\end{array}$ & $\begin{array}{l}0 \\
\text { ㅂ }\end{array}$ & $\begin{array}{l}0 \\
\text { + } \\
0\end{array}$ & $\begin{array}{l}\text { ㅁ } \\
\text { मे }\end{array}$ & 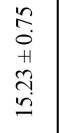 & $\begin{array}{l}\text { \# } \\
{[}\end{array}$ \\
\hline & 参哥 & $\stackrel{\varnothing}{0}$ & 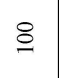 & ల్ల & ల & 요 & 8 & in & 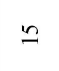 & 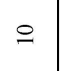 & $n$ & 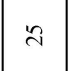 & in & 8 & 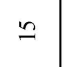 \\
\hline & 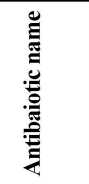 & 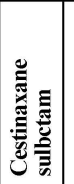 & 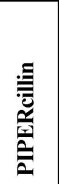 & 递 & & 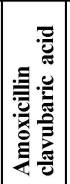 & 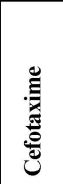 & 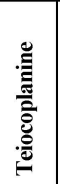 & 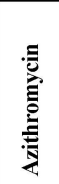 & 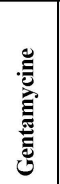 & 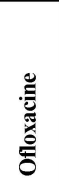 & 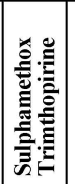 & 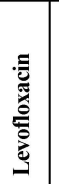 & 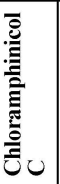 & 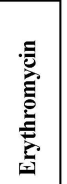 \\
\hline
\end{tabular}

Egypt. J. Microbiol. 51 (2016) 
EFFICACY OF LACTIC ACID BACTERIA ...

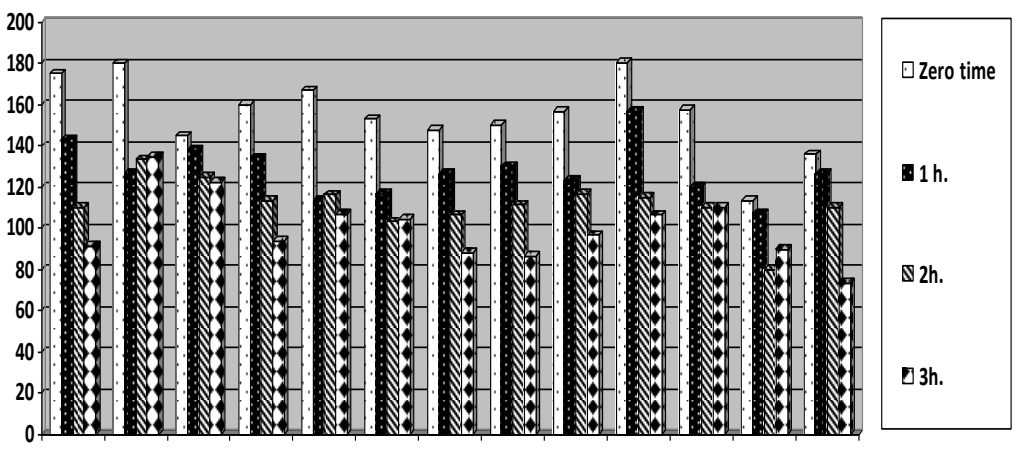

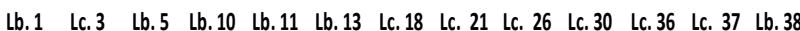

Fig. 1. Growth pattern of LAB isolates from fruits and vegetables at PH 3.0

In the present study, there was a steady increase in viable counts of only six isolates were resistant to bille saltes $0.3 \%$ concentration after 4 h exposure four of Lactobacilli strains ( $L$. plantarum 1,5 and 38 and L. brevis11) and two of Lactococci (Pediococcus sp.18 and Leuconostoc sp. 21) after culturing in bile salt but the others (7 isolates) could not maintain an appreciable level of survival after the $3^{\text {rd }} \mathrm{h}$. These isolates experienced a drop in their mean total viable counts between the $3^{\text {rd }}$ and the $4^{\text {th }}$ hours of exposure to $0.3 \%$ concentration of bile saltes in MRS broth media. Figure 2 shows the variation between the mean total viable counts at exposure to $0.3 \%$ bile salt. The $2 \%$ oxgall (bile salt) represents the extreme concentration obtained in animal or human intestins during the first hour of digestion, afterwards the normal level of bile salt in intestine is around $0.3 \%$. This tolerance is important if the strain is to be used orally as a probiotic therapeutic, since it has to tolerate a bile salt concentration of $0.1-0.3 \%$ within the human body. It has also been mentioned that the resistance to bile salts varies a great deal among the LAB species and even between the strains themselves. Bile resistance of some strains is related to a specific enzyme, bile salt hydrolase $(\mathrm{BSH})$, activity which helps hydrolyse conjugated bile, thus reducing its toxic effect (Kacem \& Karam, 2006). Oluwajoba et al. (2013) found that 5 out of 20 bacterial sp. were resistant to $\mathrm{pH} 3$, but 17 out of 20 bacterial sp. were resistant to $0.3 \%$ bile salts.

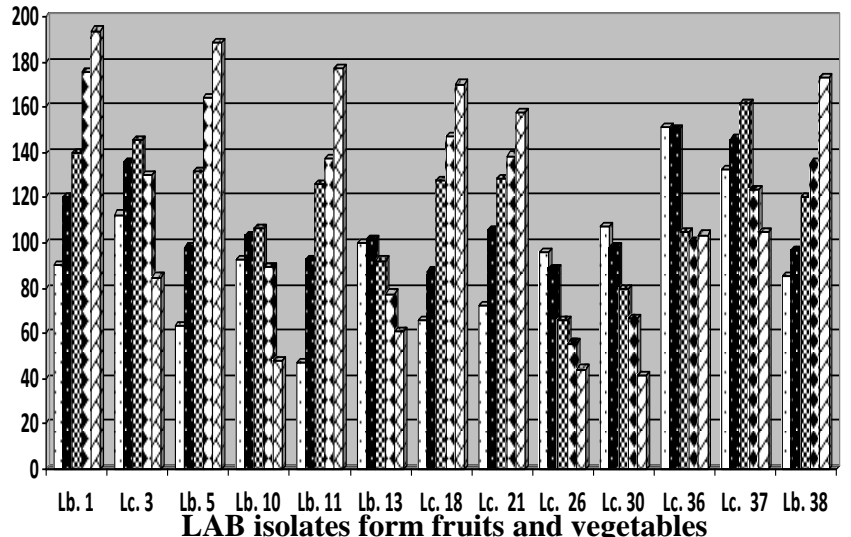

QZero time

Fig. 2. Growth pattern of LAB isolates at bile $0.3 \%$ 


\section{Conclusion and Recommendations}

The current study revealed that : Antagonistic activity of these isolated LAB genera against Staphylococcus aureus ATCC6538, Escherichia coli ATCC8739, Pseudomonas aeruginosa ATCC 9027 and Salmonella typhimurium ATCC22 bacteria were assessed, results were between what are, some isolates have a negative effect against all the tested strains, others isolates affected on some tested strains and other some isolates affected on all tested strains. In all the cases that have affected the inhibition area not exceeding $5 \mathrm{~mm}$. Sensitivity to commercial antibiotics were studied and it was noticed that the isolates showed sensitivity to antibiotics varies among the least sensitive isolate is L.sp.26 isolate where it sensitive to only one antibiotic and the most senior sensitivity were L. plantarum 5 and 27 where they were sensitive to 11 out of 14 antibiotics that were tested. Probiotic characteristics study showed that all isolates were sensitive to low stomach $ح \mathrm{H} 3$ and only 6 isolates were resistant to bille salt $0.3 \%$ concentration. We recommended by probiotic of importance to humans in many therapeutic areas, health and food industries and the lack of it presence in many fresh fruits and vegetables must support with such food sources that contains these for this particular bacteria as some fermented dairy products.

\section{References}

Adams, M.R. (1999) Safety of industrial lactic acid bacteria. J. Biotechnol. 68, 171-178.

Aslam, S. and Qazi, J.I. (2010) Isolation of acidophilic lactic acid bacteria antagonistic to microbial contaminants. Pakistan J. Zool. 42 (5), 567-73.

Axelsson, L. (1998) Lactic acid bacteria: classification and physiology. In:” Lactic Acid Bacteria: Microbiology and Functional Aspects" Salminen S., Von Wright, A., (Ed.). $3^{\text {nd }}$ rd. New York: Marcel Dekker Inc, pp. 1-72.

Bamidele Tajudeen, A., Adeniyi Bolanle, A., Ogunbanwo Samuel, T., Smith Stella I and Omonigbehin Emmanuel, A. (2011) Antibacterial activities of lactic acid bacteria isolated from selected vegetables grown in nigeria: A preliminary report, Sierra Leone Journal of Biomedical Research, 3 (3), 128-132.

Bauer, A.W., Kirby, W.M.M., Sherris, J.C. and Turck, M. (1966) Antibiotic susceptibility testing by a standardized single disk method. Am. J. Clin. Pathol. 45, 493-496. PubMed

Çakir (2003) Determination of some probiotic properties on lactobacilli and bifidobacteria PhD Thesis, Ankara University, Ankara, 2003.

Charteris, W.P., Kelly, P.M., Morelli, L. and Callins, J.K. (1997) Selection, detection, enumeration and identification of potentially probiotic Lactobacillius and Bifidobacterium species in mixed bacterial populations, International J. Food Microbiology, 35 (1), 1-27,

Egypt. J. Microbiol. 51 (2016) 
Chen, J. (2002) Microbial enzymes associated with fresh-cut produce. In: "Fresh-Cut Fruits and Vegetables" Lamikanra, O.(Ed.). pp. 249-266. CRC Press, Boca Raton, FL.

Chen, Y.S, Yanagida, F., Shinohara, T. (2005) Isolation and identification of lactic acid bacteria from soil using a $\mathrm{n}$ enrichment procedure. Letters in Appl. Microbiol. 40, 195-287.

Coppola, R., Succi, M., Tremonte, P., Reale, A., Salzano, G. and Sorrentino, E. (2005) Antibiotic susceptibility of Lactobacillus rhamnosus strains isolated from Parmigiano Reggiano cheese. Lait. 85, 193-204

Dal Bello, F. and Hertel, C. (2006) Oral cavity as natural reservoir for intestinal lactobacilli. Syst. Appl. Microbiol. 29, 69-7

Dauchet, L., Kesse-Guyot, E., Czernichow, S., Bertrais, S., Estaquio, C., Peneau, S., Vergnaud, A.C., Chat-Yung, S.,Castetbon,K.,Deschamps,V.,Brindel, P. and Hercberg, S. (2007) Dietary patterns and blood pressure change over 5-y follow-up in the SU.VI.MAX cohort. American Journal of Clinical Nutrition, 85, 1650-1656.

De Man, J.C., Rogosa, M. and Sharpe, M.E. (1960) A medium for the cultivation of lactobacilli. J Appl Bacteriol. 23, 130-135

Di Cagno, R., Surico, R.F, Siragusa, S., DeAngelis, M., Paradiso, A., Minervini, F., DeGara, L. and Gobbetti M.( 2009) Selection and use of autochthonous mixed starter for lactic acid fermentation of carrots, French beans or marrows. Int. J. Food Microbiol. 127, 220-228

Emerenini, E.C. , Afolabi, O.R., Okolie, P.I. and Akintokun, A.K. (2013) Isolation and molecular characterization of lactic acid bacteria isolated from fresh fruits and vegetables using nested pcr analysis, British Microbiology Research Journal, 3(3), 368-377.

Fatima, D. and Fernado, R.L. (2016) Characterization of bacteriocin produced by Lactobacillus brevis isolated from traditional fermented tomatoes juice, Researcher, 8 (1)

Fox, P.F. (1993) "Cheese: Chemistry Physics and Microbiology". Chapman and Hall, London. pp. 1-36.

Gebbers, J.O. (2007) Atherosclerosis, cholesterol, nutrition, and statinsea critical review. German Medical Science, 5, 1-11.

Halami, P.M., Chandrashekar, A. and Nand, K. (2000) Lactobacillus farciminis MD, a newer strain with potential for bacteriocin and antibiotic assay. Lett. Appl. Microbiol. 30,197-202

Havenaar, R., Brink, B.T., Huis In, T. and Veld, J.H.J. (1992) Selection of strains for probiotic use. In: "Probiotics. The Scientific Basis". Fuller R (Ed) Chapman and Hall, London 
He, F.J., Nowson, C.A., Lucas, M. and MacGregor, G.A. (2007) Increased consumption of fruit and vegetables is related to a reduced risk of coronary heart disease: metaanalysis of cohort studies. Journal of Human Hypertension, 21, 717-728.

Holt, J.G., Krieg, N.R., Sneath, P.H.A., Staley. J.T. and Williams, S.T. (2000) In: "Bergeys Manual of Determinative Bacteriology". Hensyl WR, editor. USA: Williams and Wilkins Philadelphia

Huyghebaert, G., Ducatelle, R. and Immerseel, F.V. (2011) An update on alternatives to antimicrobial growth promoters for broilers. Vet. J. 187, 182-188.

Jung-Min, P., Jin-Ho, S., Dan-Won, L., Jae-Chul, S., Hyung-Joo, S., Un-Jae, C., et al. (2010) Identification of the lactic acid bacteria in Kimchi according to initial and over-ripened fermentation using PCR and 16S rRNA gene sequence analysis. Food Sci. Biotechnol. 19, 541-546

Kacem, M., Karam, N.E. (2006) In vitro preselection criteria for probiotic Lactobacillus plantarum strains of fermented olive origin. Int. J. Probiotics Prebiotics, 1(1), 27-32

Kalui, C.M. Mathara, J.M. and Kutima, P.M. (2010) "Probiotic potential of spontaneously fermented cereal based foods-A review, African Journal of Biotechnology, 9 (17), 2490-2498.

Kocková, M., Gereková, P., Petruláková, Z., Hybenová, E., Šturdík, E., et al. (2011) Evaluation of fermentation properties of lactic acid bacteria isolated from sourdough. Acta Chimica, 4, 78-87.

Lee, Y.K. and Salminen, S. (1995) The coming age of probiotics. Trends Food Sci. Technol. 6 , 241-245

Lilian Sc. and Aida R.S. (2006) Lactic acid production by a strain of Lactococcus lactis subs lactis isolated from sugar cane plants. Electronic J. Biotechnol. 9, 40-44

Manzoor, A., Ul-Haq, I., Baig, S., Qazi, J.I. and Seratli, S. (2016) Efficacy of locally isolated lactic acid bacteria against antibiotic-resistant uropathogens, Jundishapur J. Microbiol. 9 (1), e18952

Mduduzi, P.M., Taurai, M. and Ademola, O.O, (2016) Perspectives on the probiotic potential of lactic acid bacteria from African traditional fermented foods and beverages, Food \& Nutrition Research. 60, 29630- http://dx.doi. org/10.3402/ fnr.v60. 29630

Nongpanga, K., Aporn, W., Duangtip, M and Sukon, T. (2008) Screening and identification of lactic acid bacteria producing antimicrobial compounds from pig gastrointestinal tracts.KMITL Sci. Tech. J. 8 (1)

Oluwajoba, S.O., Akinyosoy, F.A. and Oyetayo, V.O. (2013) In vitro screening and selection of probiotic lactic acid bacteria isolated from spontaanously fermentening Kunu-Zaki, Advances in Microbiology, 3, 309-316 
Prasad J., Gill, H., Smart, J. and Gopal, P.K. (1998) Selection and characterization of Lactobacillus and Bifidobacterium strains for use as probiotic, International Dairy Journal, 8, 12, pp. 993-1002. doi: 10.1016/ S0958-6946 (99) 00024-2

Perricone, M., Bevilacqua, A., Corbo, M.R. and Sinigaglia, M. (2014) Technological characterization and probiotic traits of yeasts isolated from Altamura sourdough to select promising microorganisms as functional starter cultures for cereal-based products. Food Microbiol. 38, 26-35.

Perricone, M., Bevilacqua, A. Altieri, C., Sinigaglia, M . and Corbo, M.R. (2015) Challenges for the production of probiotic fruit juices. Beverages, 1, 95-103

Pfeiler, EA. and Klaenhammer, T.R. (2007) The genomics of lactic acid bacteria. Trends Microbiol. 15, 546-553.

Pierre, R. (2002) Genetically modified lactic acid bacteria: Applications to food or health and risk assessment. Biochime. 84, 1073-1087.

Quwehand, A.C., Kirjavainen, P.V., Shortt, C. and. Sal- minen, S. (1999) Probiotics: mechanisms and established effects," International Dairy Journal, 9 (1), 43-52. doi:10.1016/S0958-6946(99)00043-6

Raffaella, D.C., Rosalinda, F.S., Sonya, S.M.D., Annalisa, P., Fabio, M., Laura, D.G. and Marco, G. (2013) Selection and use of autochthonous mixed starter for lactic acid fermentation of carrots French beans and marrows. Inter. J. Food Micro. 127, 220-228.

Rushdy, A.A. and Gomaa, E.Z. (2013) Antimicrobial compounds produced by probiotic Lactobacillus brevis isolated from dairy products, Ann. Microbiol. 63, 81-90.

Sarkono, Faturrahman and Sofyan, Y. (2010) Isolation and identification of lactic acid bacteria from abalone (haliotis asinina) as a potential candidate of probiotic. Biosci Biotechnol Biochem. 2, 38-42

Snedecor, G.W. and Cockran, W.G. (1969) "Statistical Methods". $6^{\text {th }}$ ed. Iowa Univ. Press. Ames. Iowa, U.S.A.

Trias, R., Bañeras, L., Badosa, E. and Montesinos, E. (2008a) Bioprotection of golden delicious apples and iceberg lettuce against foodborne bacterial

Trias, R., Bañeras, L., Montesinos, E. and Badosa, E. (2008b) Lactic acid bacteria from fresh fruit and vegetables as biocontrol agents of phytopathogenic bacteria and fungi, Int. Micro. 11, 231-236

Vandamme, P., Pot, B., Gillis, M., De Vos, P., Kersters, K. and Swings, J. (1996) Polyphasic taxonomy, a consensus approach to bacterial systematics. Microbiol. Reviews, 60, 407-438. 


\title{
فعالية بكتيريا حمض اللاكتيك المعزولة من بعض الفواكه و الخضروات \\ فريالة عبد الحميد عبد الهادى ابو سيف \\ قسم النبات ـ كلية البنات للاداب و العلوم العيد والتربية ـ جامعة عين شمس ـالقاهرة ـمصر.
}

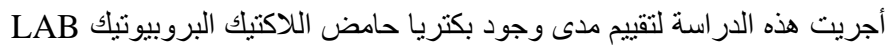

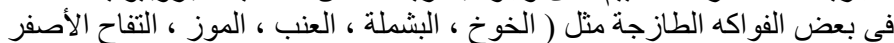

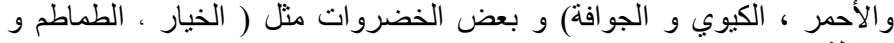
فراولة (
\end{abstract}

تم عزل ثمانية وثلاثون عزلة إيجابية لصبغ جر ام وسالبة لانتاج انزيم الكاتاليز

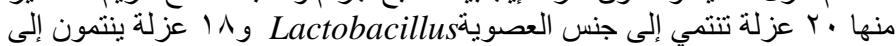
جنسى النستقة و العقدية Leuconostoc and Streptococcus .

وقد تم تقييم التائثير المضاد لهذه العزلات ضد المكورات العنقودية الذهبية

Escherichia كtaphylococcus aureus ATCC6538,

Pseudomonas aeruginosa الزائفة الزنجارية آي coli ATCC8739

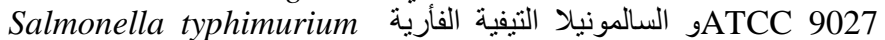

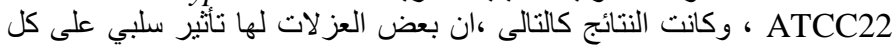

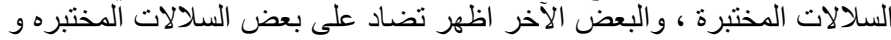

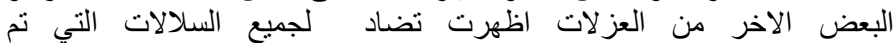

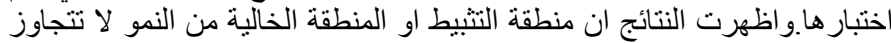

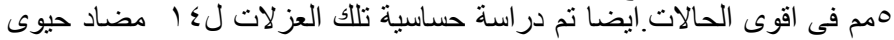

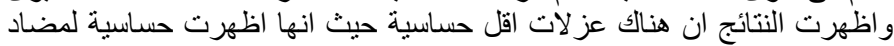

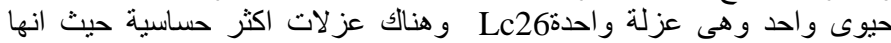

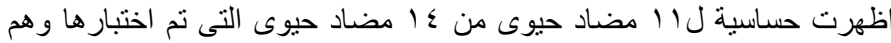

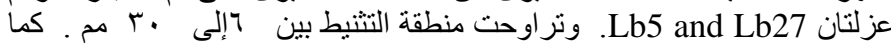

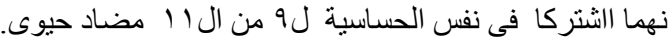

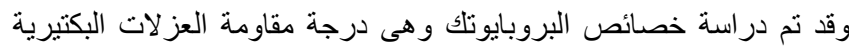

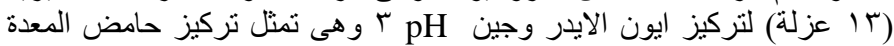

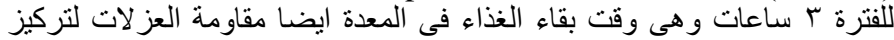
املاح الصفراء ناء

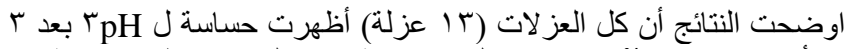

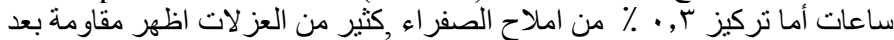

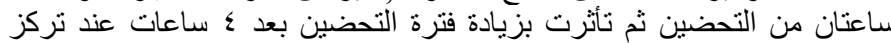

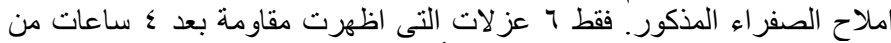

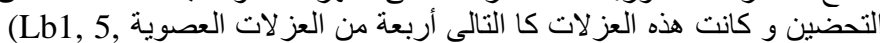

11 and 38) 